Volume 9

$10-2015$

\title{
What Does Genocide Produce? The Semantic Field of Genocide, Cultural Genocide, and Ethnocide in Indigenous Rights Discourse
}

Jeff Benvenuto

Rutgers, The State University of New Jersey

Follow this and additional works at: https://digitalcommons.usf.edu/gsp

\section{Recommended Citation}

Benvenuto, Jeff (2015) "What Does Genocide Produce? The Semantic Field of Genocide, Cultural Genocide, and Ethnocide in Indigenous Rights Discourse," Genocide Studies and Prevention: An International Journal: Vol. 9: Iss. 2: 26-40.

DOI:

http://dx.doi.org/10.5038/1911-9933.9.2.1302

Available at: https://digitalcommons.usf.edu/gsp/vol9/iss2/6

This Articles is brought to you for free and open access by the Open Access Journals at Digital Commons @ University of South Florida. It has been accepted for inclusion in Genocide Studies and Prevention: An International Journal by an authorized editor of Digital Commons @ University of South Florida. For more information, please contact digitalcommons@usf.edu. 


\title{
What Does Genocide Produce? The Semantic Field of Genocide, Cultural Genocide, and Ethnocide in Indigenous Rights Discourse
}

\author{
Jeff Benvenuto \\ Rutgers, The State University of New Jersey \\ Newark, NJ, USA
}

\begin{abstract}
The semantic field of genocide, cultural genocide, and ethnocide overlaps between Indigenous rights discourse and genocide studies. Since the 1970s, such language has been used to express grievances that have stimulated the construction of Indigenous rights in international law. These particular words signify general concerns with the integrity of Indigenous peoples, thereby undergirding a larger framework of normative beliefs, ethical arguments, and legal claims, especially the right to self-determination. Going back to the post-World War II era, this article traces the normative and institutional processes through which this overlapping discourse has emerged. Culminating with the adoption of the 2007 United Nations Declaration on the Rights of Indigenous Peoples, this process of international lawmaking has critically challenged the conventional interpretation of genocide, especially as the latter has been categorically distinguished from cultural genocide or ethnocide.
\end{abstract}

Keywords: cultural genocide, ethnocide, human rights, non-governmental organizations

\section{Introduction}

What does the keyword genocide produce? What rhetorical purpose does it serve, especially in making ethical arguments for rights? This article analyzes the political and moral functions and meanings of genocide and its related terminology, especially as they have been used as part of the vocabulary of Indigenous rights discourse. In particular, this type of language articulates the common grievances of Indigenous peoples, who have survived centuries of pressure for extermination, assimilation, and other forms of group destruction, and who in response have also launched a global resurgence in recent decades. A transnational movement in the field of Indigenous rights has fostered significant developments in the international system, as new norms in the broader field of human rights have set the minimum standards for the survival, dignity, and well-being of Indigenous peoples worldwide. The rhetoric of genocide has been partly instrumental in this political process, going back to the origins of "Indigenous global politics" in the 1970s. ${ }^{1}$

This movement dates back to September 1977, when over 100 Indigenous delegations and 60 non-governmental organizations (NGOs), along with a few United Nations (UN) functionaries and state government observers, met at the Palais des Nations in Geneva, Switzerland. They were attending the International NGO Conference on Discrimination against Indigenous Populations in the Americas (hereafter, simply the 1977 NGO Conference). ${ }^{2}$ This event was a significant turning point in the normative and institutional developments that eventually resulted in the adoption of the 1989 International Labour Organization (ILO) Convention No. 169 and the 2007 UN Declaration on the Rights of Indigenous Peoples (hereafter, simply the 2007 Declaration). The latter is now the cornerstone of the field of Indigenous rights, which took decades to transform into international law. This process of international legalization was initially mobilized by a transnational advocacy network that coalesced at the 1977 NGO Conference. ${ }^{3}$

The core of this advocacy network was strongly motivated by a collective sense of moral indignation against the enduring injustices of colonialism. Such a sentiment was evident in the "Declaration of Principles" adopted at the 1977 NGO Conference. Its preamble began by acknowledging the activity of the UN in promoting human rights and fundamental freedoms, while also "recognizing that conditions are imposed upon peoples that suppress, deny or destroy the culture, societies or nations in which they believe or of which they are members." ${ }^{4}$ This explicit emphasis on the threats to Indigenous peoples provided a sense of urgency for the subsequent enumeration of rights oriented around the principle of self-determination. Even though the specific vocabulary of genocide, cultural genocide, and ethnocide were not actually used in the "Declaration of Principles," these were widely discussed keywords at the 1977 NGO Conference, where their conventional meanings were fundamentally challenged as well. ${ }^{5}$ 
For example, one delegate admitted to not being well versed in international law, but she was nevertheless convinced that "in the limited dictionary of ordinary people everywhere in the world there is no other word to describe it but genocide." ${ }^{\prime 6}$ In this way, the term functioned as a somewhat essentialized, short-hand expression used to emphatically draw attention to ongoing threats to the physical and cultural integrity of Indigenous peoples. Such a construal implied the moral equivalence between the attempted biological-physical and socio-cultural destruction of a group, respectively. In this way, the 1977 NGO Conference participants collapsed a categorical distinction in the international legal canon of genocide, foreshadowing the contemporary debate over the role of cultural genocide in recent cases. ${ }^{7}$

Nevertheless, the conference participants acknowledged the definitional limitations of the 1948 United Nations Convention on the Prevention and Punishment of the Crime of Genocide (UNGC), which categorically distinguished the strictly legal meaning of genocide from the related notions of cultural genocide and ethnocide. ${ }^{8}$ Faced with this conceptual impasse, one of the conference's organized sub-bodies, the Social and Cultural Commission, resolved that "ethnocide must be defined as both a cause and a part of genocide." ${ }^{\prime 9}$ By collapsing this distinction, the 1977 NGO Conference attempted to open up a new way to approach peoples' fundamental right to exist. Using this historical vignette as a point of departure, the following analysis argues that the semantic field of genocide, cultural genocide, and ethnocide has not only stimulated the production of Indigenous rights in international law, but that Indigenous rights discourse has also opened up new ways of understanding the inherent connections between these associated keywords.

\section{Between Indigenous Rights and Genocide Studies}

The close conceptual pairing in Indigenous rights discourse of genocide, on the one hand, and cultural genocide or ethnocide, on the other, foreshadowed the recent colonial turn in genocide studies. Since the early 2000s, a more Lemkinian approach has returned to the field in conjunction with emerging scholarship on settler colonialism..$^{10}$ Such work has been directed towards what Patrick Wolfe calls the "logic of elimination," referring to a certain structural tendency of settler colonial formations that sometimes converges with genocide but is otherwise distinct. This conceptualization enables Wolfe to "regard assimilation as itself a form of destruction" without having to make the case for genocide, per se, while also avoiding what he sees as the awkwardness of the term cultural genocide. ${ }^{11}$ Other scholars, like Damien Short, go further in suggesting the possibility that forcible assimilation is a sufficient condition for genocide, while Dirk Moses represents a more moderate position, contending that cultural destruction must be accompanied by physical and biological attacks in order to qualify as genocide. ${ }^{12}$ Even within the colonial genocide studies literature, then, there is disagreement as to how forced assimilation and cultural destruction fit into the conceptual framework of the field. Nevertheless, this scholarship has pushed towards a conception of genocide as a form of group destruction rather than simply the mass murder of individuals. ${ }^{13}$ This way of thinking corresponds to many of the arguments and assumptions in Indigenous rights discourse.

Between indigenous rights discourse and genocide studies are a number of important connections that can be made with other relevant research programs. The 1977 NGO Conference especially fits into the alternative historiography of human rights exemplified by the works of Samuel Moyn and Jan Eckel. They critique the basic idea of human rights as a specifically postWorld War II phenomenon and instead argue that the norms and institutions crafted during the 1940s were at first stillborn with the Great Power politics involved with the creation of the UN, as well as with the subsequent arrival of the Cold War and decolonization, only to suddenly flourish in the 1970s, just as the global Indigenous rights movement began to rise. Moyn even stresses that 1977, the same year as the NGO Conference, was more generally the "breakthrough year" in the history of human rights, given the inauguration of American President Jimmy Carter and the awarding of the Nobel Peace Prize to Amnesty International. ${ }^{14}$ While such historiography has yet to pay much attention to Indigenous peoples, ${ }^{15}$ anthropologists have observed and sometimes even participated as advocates in the process of transforming Indigenous rights into international law. Moreover, ethnographic methods have demonstrated the ways in which global discourses of human/indigenous rights are appropriated and translated through social practices from various localities around the world. ${ }^{16}$ Finally, the significance of Indigenous rights discourse can also be 
explained across the even more general field of constructivism in international relations theory, considering an array of relevant concepts like transnational advocacy networks, non-state actors, global civil society, international norms, state compliance, and domestic change. ${ }^{17}$

A common pattern identified throughout this various scholarship concerns how normative beliefs and ethical arguments are used as political resources to critique status quo relations. In genocide studies, for example, Moses brings attention to the affective dimension of genocide as a keyword, especially as it has been used to express "the traumatic consciousness of group subjugation or destruction," while other scholars demonstrate how charges of genocide are tied to political claims for self-determination..$^{18}$ From Indigenous studies, meanwhile, Ronald Niezen refers to "the politics of indignation" to describe how targeted groups attempt to gain empathy and possibly influence public opinion by appropriating the images, narratives, and frames that signify their social suffering. ${ }^{19}$ He extends this idea to his ethnographic study of the Canadian Truth and Reconciliation Commission, where he argues that the expression of rights-based claims against perceived injustices have become a source of collective meaning and identity. This type of analysis, he says, is "as much concerned with the socially constructive power of rights as with the destructive power of wrongs." 20

Following such insights, this article is concerned with what the semantic field of genocide, cultural genocide, and ethnocide has to offer advocates of Indigenous rights. Whereas another scholar recently asked, "what do genocides kill?," ${ }^{21}$ I instead wonder, "what does genocide produce?"22 By employing italicized text for these keywords, I am drawing attention to the rhetorical and political effects of this type of language in expressing certain normative beliefs and ethical arguments that are used to help make the case for Indigenous rights. This rhetorical approach is concerned with genocide and its related keywords as means of persuasion and is not meant to suggest that such claims are unduly exaggerated or bombastic. With this in mind, I will explain how the conventional meaning of genocide in international law been challenged by Indigenous rights discourse. At the same time, I will demonstrate how the semantic field surrounding this keyword has been used to help construct Indigenous rights discourse in the first place.

\section{Genocide and Integration in Post-World War II International Law}

In order to see the political and institutional changes in Indigenous rights discourse after the 1970s, prior historical context is necessary to first understand how colonial beliefs and practices regarding Indigenous peoples were perpetuated in the post-World War II era. There is already a rich body of scholarship on the creation of the UNGC, with particular attention on the diplomatic wrangling involved with the removal of cultural genocide from the final text. ${ }^{23}$ By juxtaposing the 1948 UNGC with the 1951 ILO Convention No. 107 (the Convention concerning the Protection and Integration of Indigenous and Other Tribal and Semi-Tribal Populations in Independent Countries), the following critical analysis will examine some of the background assumptions, biases, and blindspots operating within the international institutions of the time. ${ }^{24}$ Both of these instruments failed to protect Indigenous peoples from forcible assimilation and group destruction. Rather, they both appear to have been created under the assumption that sovereign states were obliged to integrate these stigmatized populations into dominant national units.

Such a colonialist assumption was apparent with two of the most well-known arguments against the inclusion of cultural genocide in the UNGC. The first was that the practices of assimilation and integration typically connoted by cultural genocide or ethnocide did not meet the legal requirement of genocidal intent. According to this definitional standard, as determined by the expert panel behind the 1947 Secretariat draft, "certain acts which may result in the total or partial destruction of a group of human beings are in principle excluded from the notion of genocide, namely ... the policy of compulsory assimilation of a national element." ${ }^{25}$ Even Raphael Lemkin agreed that "cultural genocide was much more than just a policy of forced assimilation by moderate coercion." ${ }^{26}$ Elsewhere he suggested that, "when exposed to strong outside influences," the continued existence of certain groups depended on "cultural diffusion," even if "it may lead to the eventual disintegration of a weak culture." 27 The misconception that Indigenous peoples were somehow anemic and destined to vanish thus informed the argument that forced assimilation was not genocidal due to its general lack of specific intent. 
The second argument against the inclusion of cultural genocide from the final text of the UNGC was more of a departure from Lemkin's thought, however. As discussed elsewhere, Lemkin understood the "genos" of genocide in group-oriented terms that harkened back to Johann Gottfried Herder and the intellectual legacy of romanticism in Central Eastern Europe. ${ }^{28}$ This type of intellectual orientation towards group rights was more prevalent during the previous interwar period, when it was misappropriated by fascist and other right-wing organic nationalists. Of course, the minority rights regime of the League of Nations ended in catastrophic failure, and with the postwar creation of the UN, there was a major normative shift towards the universal human rights of individuals. In this context, Lemkin's thinking about group rights was outdated, and his conception of genocide that included cultural destruction was flatly rejected by certain member states. ${ }^{29}$ In General Assembly deliberations over the final text of the UNGC, for example, the United States delegate suggested that the notion of group rights underpinning the idea of cultural genocide was moot so long as individual rights were assured. ${ }^{30}$

With such conceptual blinders in place, the topic of Indigenous peoples was hardly discussed while drafting the UNGC. The few times it was mentioned, it was typically framed in terms of a social evolutionary paradigm that still retained intellectual force after World War II, despite the ostensible delegitimization of scientific racism. For example, the Brazilian delegate suggested that, "given the historical evolution of civilizations, a State might be justified in its endeavor to achieve by legal means a certain degree of homogeneity and culture within its boundaries." ${ }^{11}$ Under this pretext, Indigenous peoples were deemed to be legitimate targets for socioeconomic and cultural integration into dominant national units. This attitude was further evident with the Venezuelan representative, who had otherwise supported the inclusion of cultural genocide, at least in a limited form. But the transfer of children, he said in reference to what would become Article II (e) of the final draft, "might be made from a group with a low standard of civilization and living in conditions both unhealthy and primitive, to a highly civilized group as members of which the children would suffer no physical harm and would indeed enjoy an existence which was materially better." ${ }^{12} \mathrm{He}$ was thus concerned that this provision would fundamentally undermine the presumed legitimacy of state integrationist policies.

In the historical context of the postwar transformation of the international system, this type of colonial belief and practice of integration was apparent throughout the world. Even as European empires were being dismantled, the colonization of Indigenous peoples continued unabated. The official process of decolonization was strictly limited to "non-self-governing territories" that were geographically separated from imperial metropoles, and the so-called "salt-water thesis" of decolonization effectively legitimized the "internal colonialism" experienced by Indigenous peoples and their territories. ${ }^{33}$ In this context, as developmentalism and other theories of modernization began to globally disseminate by the 1950s, integration became an important keyword in the social engineering of modern economies, states, and nations. ${ }^{34}$ In his analysis of the ILO regime and Indigenous peoples, Luis Rodríguez-Piñero has demonstrated how central this integrative approach was to ILO Convention No. $107 .{ }^{35}$

The International Labour Organization was first established in 1919 as a principle organ of the League of Nations, the latter of which was dedicated to, among other things, what it called "a sacred trust of civilization." ${ }^{36}$ In the vein of reforming colonial policies, the ILO began studying the conditions of "Indigenous workers" in certain parts of the world during the interwar period. By the 1940s, the ILO began responding to a growing normative shift across the Americas known as indigenismo. According to a recent study of this diverse political, economic, and cultural movement, indigenismo "celebrated indigenous people and their traditions, on the one hand, but usually also called for their modernization, assimilation, and 'improvement,' on the other." ${ }^{37}$ This intellectual current effectively reframed the so-called "Indian problem" into a public policy issue concerned with addressing the poor socioeconomic status of Indigenous populations, and it was from this perspective that the ILO formulated the first international standards dedicated to Indigenous peoples.

ILO Convention No. 107 was thus conceived under the basic assumptions that "tribal or semitribal populations" were at a "less advanced stage" of development, and that "Governments shall have the primary responsibility for developing coordinated and systematic action for the protection 
of the populations concerned and their progressive integration into the life of their respective countries." ${ }^{38}$ Pursuant to this ostensibly benevolent pretense, the protocol mostly enumerated a number of duties for states, although a few rights were granted to Indigenous peoples, such as the right to maintain customary laws and institutions. ${ }^{39}$ On the surface, then, ILO Convention No. 107 provided at least some measure of protection for the physical and cultural existence of Indigenous peoples, although such recognition was only temporary, insofar as it was expected to ease the process of integration. In the end, ILO Convention No. 107 was only ratified by a mere 27 countries, the majority of which were from the Americas,$^{40}$ although it nevertheless epitomized a more global trend at the time concerning the integration of Indigenous peoples as part of the larger ideological framework of modernization.

\section{A Normative Shift After the 1970s}

As elaborated below, ILO Convention No. 107 was replaced in 1989 by ILO Convention No. 169. In the three-decade-long period between these two instruments, there was a major normative shift away from an emphasis on state integrationist policies in favor of a rights-based sensibility constructed around the principle of self-determination. ${ }^{41}$ This transformation was underway during the 1970s and 1980s, when developments in the human rights agenda at the UN led to a partial overlap between Indigenous rights discourse and genocide studies and prevention. In particular, there was dialogue between two Special Rapporteurs assigned by the UN Sub-Commission on the Prevention of Discrimination and Protection of Minorities (hereafter, simply the Sub-Commission). ${ }^{42}$ During its 24th session in August 1971, the Sub-Commission assigned Nicodème Ruhashyankiko to prepare a report on the prevention and punishment of genocide, which he completed in 1978 (this was followed by a second genocide report by Benjamin Whitaker in 1985). The same session of the Sub-Commission also authorized José Martínez Cobo, who released his monumental study on Indigenous peoples in piecemeal from 1981 to 1983. These experts were independently tasked with reviewing relevant scholarship, case law, official documentation, and government responses to requests for information in order to prepare reports for the UN Commission on Human Rights, of which the Sub-Commission was a subordinate body. Although they were undertaken as separate endeavors, these two sets of reports indicate an overlapping concern with situating the concepts of cultural genocide and ethnocide in relation to the prevention and punishment of genocide.

An examination of some of the footnotes in the two Sub-Commission reports on genocide - the first by Ruhashyankiko in the 1970s and the second by Whitaker during the 1980s - suggests that new meanings of cultural genocide and ethnocide were being produced at the time. For example, Ruhashyankiko cited the French ethnographer Robert Jaulin, who essentially recoined to idea of ethnocide to pose as an alternative to the UNGC. ${ }^{43}$ Following his fieldwork in Latin America during the 1960s, Jaulin used the concept of ethnocide to describe what he considered to be the predatory impulse of Western civilization in consuming and destroying the world's cultural diversity. He implied that this type of group destruction was conceptually distinguishable from intentional physical annihilation, and in this vein, he tacitly maintained the conventional rendering of genocide as categorically distinct from ethnocide. Nevertheless, his usage of ethnocide was revolutionary, insofar as it implied a moral equivalence to genocide, per se. ${ }^{44}$ To be clear, Ruhashyankiko was not endorsing this particular point in his Sub-Commission report, but the fact that he cited Jaulin nevertheless indicates that alternative approaches were beginning to surface.

For entirely unrelated reasons, the publication of the Ruhashyankiko report was soon shrouded in controversy, and by 1982 the Sub-Commission authorized Benjamin Whitaker to prepare a revised and updated report on genocide, the footnotes of which also indicate changes in Indigenous rights discourse. ${ }^{45}$ For example, Whitaker referenced a 1976 edited volume by the international legal scholar Richard Arens, who was instrumental in bringing attention to the case of the Aché people in Paraguay. ${ }^{46}$ During the 1970s, the Aché had become a minor cause célèbre, especially among Western European and American anthropologists doing fieldwork in Latin America. Operating through newly created NGOs like the International Work Group on Indigenous Affairs (IWGIA), a network of scholars and advocates began using the term genocide to raise global awareness of the Aché. This language was often used self-evidently, as if it was without question a natural descriptor of the situation. Such loose rhetoric became the source of a heated 
controversy among non-Indigenous activists. ${ }^{47}$ That this semantic debate even occurred, however, indicates that genocide was becoming conceptually unmoored from its legalistic constraints, and was instead being communicated on an affective level. This was evident in the epilogue of Arens' volume, which was authored by Elie Wiesel, the famous Holocaust survivor who rescinded his belief in the uniqueness of the Shoah, at least in this case. ${ }^{48}$ While it is important not to overstate the significance of such footnotes in the respective genocide reports for the Sub-Commission, this evidence suggests that intellectual changes were underway.

This normative shift is further apparent with the brief dialogue between the two SubCommission reports on genocide, on the one hand, and the "Study of the Problem of Discrimination against Indigenous Populations" by Special Rapporteur Cobo, on the other. Most well-known for its influential attempt to define "Indigenous peoples," 49 the Cobo report was comprehensive in scope and was very important in informing ongoing deliberations elsewhere in the Sub-Commission regarding the development of Indigenous rights. In this regard, Cobo's brief discussion of genocide, cultural genocide, and ethnocide was used in the context of discussing the particular right of Indigenous peoples to protect, maintain, and develop their own customs and institutions. Drawing from Ruhashyankiko's review of the definitional debate surrounding the UNGC, Cobo concluded that "the question whether ethnocide is or is not a form of genocide is important, but however it is decided the fact remains that ethnocide consists of a series of serious violations of human rights which resemble genocide and which must be forestalled and punished. ${ }^{\prime \prime 50}$ In identifying a lacuna surrounding this concept in international law, the Cobo report in turn prompted the subsequent Whitaker to reconsider the possibilities of bringing cultural genocide or ethnocide back into the definitional fold of the international law against genocide. ${ }^{51}$ This dialogue between Cobo and the two Sub-Commission reports on genocide not only indicates the relevance of this particular semantic field in the construction of Indigenous rights, but also that Indigenous rights discourse was also instigating conceptual changes in the field of genocide studies and prevention.

This was further evident with the Declaration of San José produced by the 1981 UNESCO Conference on Ethnocide and Ethnodevelopment. Although this meeting had no official capacity to promulgate international law, it nevertheless provided a formal setting to propose working standards that would subsequently mature with the drafting of the 2007 Declaration. In this fashion, the 1981 Declaration of San José defined ethnocide as the denial of an ethnic group's "right to enjoy, develop and transmit its own culture and its own language, whether collectively or individually," adding that, for transgressing the right to culture, it should be considered "a violation of international law equivalent to genocide".$^{52}$ In order to prevent and repair this particular offense, the concept of ethnodevelopment was proposed in order to promote "the independent decisionmaking capacity of a culturally distinct society to direct its own development and exercise of selfdetermination, at whatever level." ${ }^{153}$ As such, the conceptual structure of the 1981 Declaration of San José shows ethnocide was used in Indigenous rights discourse to signify the need for a new type of international legal prohibition specifically tailored to support a more positive and prescriptive set of rights associated with the principle of self-determination.

By the 1980s, these various developments marked a profound shift in Indigenous rights discourse from an emphasis on integration to self-determination. As noted, this shift was so profound that ILO Convention No. 107 was eventually replaced altogether in 1989 with a new protocol, ILO Convention No. 169, otherwise known as the Indigenous and Tribal Peoples Convention. Although the semantic field of genocide, cultural genocide, and ethnocide was not specifically covered in ILO Convention No. 169, its preamble tacitly alluded to the general spirit of these concepts, especially as it denounced "the assimilationist orientation of the earlier standards." Instead, ILO Convention No. 169 recognized "the aspirations of these peoples to exercise control over their own institutions, ways of life and economic development and to maintain and develop their identities, languages and religions, within the framework of the States in which they live." 54 As explained below, the fact that the specific language of self-determination was carefully avoided here indicates that there were limits to the normative shift of Indigenous rights. Nevertheless, the preceding analysis suggests that the transnational advocacy network of Indigenous rights was largely able to set the terms of subsequent debates that eventually culminated with the adoption of the 2007 Declaration. 


\section{Contested Limits and Boundaries Since the 1980s}

Despite evidencing a normative shift away from previous standards, ILO Convention No. 169 still imposed certain boundaries on Indigenous rights. Indeed, the keyword "peoples" as part of the very title of ILO Convention No. 169 was strongly contested by state governments that were suspicious of the term's associations with self-determination and secessionist claims. They generally preferred to instead retain the specific language of "populations" from the title of ILO Convention No. 107, given its domesticating connotations. Ultimately, an unequal compromise was reached when the use of the term "peoples" was strictly limited in a way that "shall not be construed as having any implications as regards the rights which may attach to the term under international law." ${ }^{\prime 55} \mathrm{~A}$ similar safeguard was eventually built into the final text of the 2007 Declaration, which concluded by assuring that "Nothing in this Declaration may be interpreted as implying for any State, people, group or person any right to engage in any activity or to perform any act contrary to the Charter of the United Nations or construed as authorizing or encouraging any action which would dismember or impair, totally or in part, the territorial integrity or political unity of sovereign and independent States." ${ }^{56}$ Despite their many differences in form, content, and legal status, both ILO Convention No. 169 of 1989 and the 2007 Declaration similarly limit the meaning of Indigenous rights in the traditionally state-centric international system.

Yet unlike the creation of ILO Convention No. 169, in which Indigenous organizations and advocates were unable to directly participate, ${ }^{57}$ this transnational advocacy network enjoyed a more proactive role in the origins of the 2007 Declaration. This dates back to 1982, when the SubCommission established a Working Group on Indigenous Populations (hereafter referred to as the Sub-Commission Working Group), which was mandated to review pertinent developments in human rights with special attention to "the evolution of standards" concerning Indigenous peoples. ${ }^{58}$ Its exceptional participation policy did not require formal consultative status with the UN in order for Indigenous representatives to partake, and this enabled the Sub-Commission to grow in size and stature. By the end of the decade, its sessions were drawing over 1,000 participants, giving this body a high profile despite its relatively low level in the UN organization. ${ }^{59}$ These conditions enabled some participants to push the limits of the Sub-Commission Working Group's mandate by "naming and shaming" certain states accused of political violence and genocidal practices. One close observer noted that the Sub-Commission Working Group turned into "a forum for airing grievances." ${ }^{60}$ Under such circumstances, however, the long-standing Chairperson-Rapporteur of the Sub-Commission Working Group, Erica-Irene Daes, did her best to ensure that this forum did not devolve into a "chamber of complaints," ${ }^{61}$ and that such charges would instead add a sense of urgency to their work in developing a first draft to what would eventually become the 2007 Declaration.

In finalizing this first draft (hereafter referred to as the $1994 \mathrm{draft}){ }^{62}$ the Sub-Commission Working Group promoted new meanings for genocide, cultural genocide, and ethnocide. Given their unparalleled access to the Sub-Commission Working Group, Indigenous organizations and advocates were influential in setting the terms for the remainder of the drafting process, and the 1994 draft is considered by some observers to be the most progressive version of Indigenous rights. ${ }^{63}$ However, the form and content of the $1994 \mathrm{draft}$ was altered as it subsequently moved up the UN system. In 1995, the Commission on Human Rights (CHR) created a new working group (hereafter referred to as the CHR Working Group) which, unlike its predecessor, was primarily comprised of member state delegations. Indigenous organizations and advocates struggled to retain the influence they had previously enjoyed, and in turn they protested their marginalization, walking out of the 1996 session and going on hunger strike in $2004 .{ }^{64}$ In this context, the CHR Working Group prepared what is referred to as the $2006 \mathrm{draft}$, in which revisions were made without the consent of Indigenous participants. A third and final round of revisions was then made by the General Assembly before it ultimately adopted the 2007 Declaration. A comparison of these three texts indicates that state-imposed limits to Indigenous rights discourse also restrained the extent to which new meanings of genocide, cultural genocide, and ethnocide were promoted.

To begin with, the Sub-Commission Working Group operated under the premise that existing human rights standards were insufficient, and that certain adaptations and innovations were needed in order to meet the needs and aspirations of Indigenous peoples. In some cases, 
already existent standards were tweaked, as with Article 6 of the $1994 \mathrm{draft}$, which concerned genocide. As originally established by the UNGC, the conventional emphasis of genocide was on the individual right to life and physical integrity, but Article 6 of the 1994 draft deemphasized this individualist interpretation. Instead, it identified genocide ${ }^{65} \mathrm{It}$ is worth noting that, despite already being included in the international law of genocide, forcible child removal was singled out here for special attention, as this had become a global pattern of genocide against Indigenous peoples.

Whereas Article 6 of the 1994 draft was a modification of an already existent norm, Article 7 promoted the conceptual duo of cultural genocide and ethnocide as an entirely new standard in international law. Article 7 thus began by declaring that "Indigenous peoples have the collective and individual right not to be subjected to ethnocide and cultural genocide," which it described as the deprivation of cultural values and ethnic identities, the dispossession of lands, territories, and resources, as well as "any form of assimilation or integration by other cultures or ways of life imposed on them by legislative, administrative or other measures." 66 There was some confusion, however, as to the precise relationship between the concepts of cultural genocide and ethnocide. This lack of clarity was raised by the Language Services of the United Nations, which reviewed the 1994 draft before it proceeded to the CHR. Following the reasoning of Chairperson-Rapporteur Daes, the Language Services report concluded "that 'cultural genocide' referred to the destruction of the physical aspects of a culture, while 'ethnocide' referred to the elimination of an entire 'ethnos' or people." ${ }^{67}$ No further elaboration of this distinction appears in the records, and the question remains as to how "the physical aspects of a culture" is understood separately from its so-called "ethnos." Taking advantage of this conceptual confusion, some member states, especially Canada, Chile, and the United States, were immediately critical of this particular provision in the 1994 draft. ${ }^{68}$

Indeed, as the second phase of the drafting process began with the CHR Working Group in 1995, the influence of member states increased vis-à-vis Indigenous peoples. In this setting of unequal power relations, some of the colonial assumptions analyzed above with regards to the drafting of the UNGC resurfaced a half-century later in the context of Indigenous rights discourse. For example, some states were concerned with the 1994 draft's absolute prohibition against Indigenous child removal. According to the records from the first session of the CHR Working Group:

With regard to article 6, several Governments expressed the difficulties they had with the phrase "under any pretext" as contained in its first paragraph. They stated that there were circumstances under which it was in the child's interest to be removed from their families and communities, whether the child was indigenous or non-indigenous. It was felt that in these circumstances indigenous people and communities should not receive preferential treatment over others since this could turn out to be harmful to the child. ${ }^{69}$

Although the particular emphasis on the forcible removal of children originally established in Article 6 of the 1994 draft was ultimately retained in what became Article 7 of the $2006 \mathrm{draft}$ (note that the numbering of the articles was altered in the process), it appears that member states were committed to limiting the meaning of this provision.

Accordingly, Article 7 of the 2006 draft reversed the syntax from what was originally Article 6 in the 1994 version. The new text established by the CHR Working Group emphasized that the prohibition of genocide was first and foremost a guarantee of the individual right to life and physical integrity. Only then did the revised text acknowledge that genocide also covered "the collective right to live ... as distinct peoples." ${ }^{\prime 70}$ Moreover, whereas this provision the $1994 \mathrm{draft}$ was more rigorous in providing "full guarantees against genocide," the 2006 draft merely stated that Indigenous peoples "shall not be subject to any act of genocide." ${ }^{\prime 71}$ Equally subtle yet significant changes were also apparent in Article 8 of the 2006 draft (formerly Article 7 of the $1994 \mathrm{draft}$ ), the revised text of which began by declaring that "Indigenous peoples and individuals have the right not to be subjected to forced assimilation or destruction of their culture."72 Removed was the earlier qualification that this was both a collective and individual right. More significantly, however, this second draft prepared by CHR Working Group deleted the specific language of cultural genocide 
and ethnocide, which were instead replaced by more generic descriptors. It thus seems that these terms were too controversial and imprecise, even though their general spirit was retained.

When the 2006 draft was delivered to the Third Committee of the General Assembly (GA) for final approval, important textual changes were made in order to reaffirm the sovereign authority of state governments over Indigenous peoples. Almost immediately, a bloc of African states protested that the proposed right to self-determination would lead to secessionist movements. With the support of the CANZUS countries (Canada, Australia, New Zealand, and the United States), the African bloc moved to defer the final vote until the inviolability of state sovereignty was explicitly guaranteed in order to limit the extent of Indigenous rights. ${ }^{73}$ Following this, the provision against forced assimilation and cultural destruction was slightly amended and diminished in this third and final round of revisions. Article 8(2)(d) of the 2006 draft retained the original language from the 1994 version, which prohibited "any form of forced assimilation by other cultures or ways of life imposed on them by legislative, administrative or other measures." However, the final text of the 2007 Declaration deleted reference to "legislative, administrative or other measures," thereby effectively taking the onus of off the state as a primary agent of such transgressions. ${ }^{74}$ This was just one of several last-minute revisions that ultimately reaffirmed the sovereign authority of states and restrained the claims for Indigenous rights.

\section{Conclusion}

The preceding analysis demonstrates the imposition of structural and discursive boundaries in the development of Indigenous rights. Despite the fact that the transnational advocacy network of Indigenous rights may have provided the initial inspiration for ILO Convention No. 169 and the 2007 Declaration, it is also true that state governments retained the final authority in formalizing these processes of international lawmaking. With these instruments' subsequent and ongoing processes of domestic compliance, moreover, the acquiescence of state governments is ultimately necessary in order to ensure their implementation and enforcement. Indeed, the very act of defining state obligations in regards to the international legalization of Indigenous rights has effectively reinforced the superior sovereign status of nation states over the autonomy of Indigenous peoples. ${ }^{75}$ This reflects the underlying structuring of the international system, which despite promises since the post-World War II era to shift the focus of international law from states to people, nevertheless remains fundamentally state-centric.

In addition to these structural limitations, there have also been discursive constraints in the process of translating Indigenous peoples' claims into the idioms of international law. Despite the ostensibly progressive appeal of human rights discourse, this broad field is still troubled by its association with Eurocentric and colonial tendencies to marginalize the many alternative ways of being, thinking, and doing represented by the world's Indigenous peoples. ${ }^{76}$ Irene Watson argues that, "instead of protecting Aboriginal peoples, 'human rights' bring to order our regulation and containment. That is because the keepers of power determine the questions of humanity and that which constitutes the rights of humans, and they are ultimately positioned to enable or disable humanity."77 It is thus reasonable to be critical of the international legal and political discourses associated with universal human rights, as well as to appreciate how Indigenous claims are premised upon their own unique sources of power and legitimacy. ${ }^{78}$

Yet despite the possibility that rights discourse in global affairs is reproducing colonial relations of power, it is also apparent that important changes in international law have been advanced nevertheless. For example, James Anaya demonstrates how Indigenous rights discourse has contributed to a newer and more flexible set of meanings for self-determination, which is no longer strictly defined by the achievement of independent statehood, but rather by the recognition of and respect for Indigenous peoples as self-governing entities entitled to fully participate in the decisions affecting their lives. This general principle undergirds an assorted array of more specific norms, including the right to cultural integrity, which has also fruitfully developed in the field of human rights as a result of Indigenous rights discourse. ${ }^{79}$ Articles 7 and 8 of the 2007 Declaration are thus an extension of this broader development behind the cultural integrity norm, and it is in this context that the semantic field of genocide, cultural genocide, and ethnocide is significant. It is not the case that such rhetoric has simply been used as "strategic weapons" in political movements 
for secession..$^{80}$ Rather, these keywords signify a general concern with protecting the continued existence of Indigenous peoples as a crucial element in a larger framework of rights. ${ }^{81}$

As a result of the normative and institutional developments behind the construction of Indigenous rights, new meanings for the semantic field of genocide, cultural genocide, and ethnocide have been produced. The conventional interpretation established by the UNGC, whereby genocide was categorically distinguished from cultural genocide and ethnocide, has been critically challenged. More assertive versions of Indigenous rights discourse, as with the 1977 NGO Conference, for example, underscore the intrinsic connections across this semantic field, suggesting that "ethnocide must be defined as both a cause and a part of genocide," and that there should be a legal equivalence between the two. ${ }^{82}$ The more moderate version established by the 2007 Declaration merely juxtaposes genocide alongside the apparently synonymous concepts of cultural genocide and ethnocide. Although the latter pair represents a new international legal norm with a relatively "softer" status, at least compared with the international customary law against genocide, ${ }^{83}$ the juxtaposition of these two provisions in the 2007 Declaration suggests at least a moral equivalence between the physical and cultural destruction of a group.

In conclusion, the field of genocide studies should embrace the ongoing dialogue with Indigenous rights discourse and its associated field of Indigenous studies. This intellectual exchange dates back to the 1970s, and it continues with the contemporary flourishing of the colonial genocide studies literature. The recent emergence of a nascent approach referred to as "decolonizing genocide studies," which attempts to destabilize some of the foundational assumptions and biases of the field in order to open space for Indigenous ways of knowing, has furthered this dialogue. ${ }^{84}$ Not only does this new approach promise epistemological insights into the nature of genocide as a broad category of group destruction, but it also poses important methodological and ethical challenges regarding the legal and political implications of genocide studies. Indeed, as the semantic field of genocide, cultural genocide, and ethnocide continues to be deployed by the transnational advocacy network for Indigenous rights, genocide scholars must revisit our field's perennial concern with the balance between scholarship and activism.

\section{Endnotes}

1 Sheryl Rae Lightfoot, “Indigenous Global Politics” (PhD diss., University of Minnesota, 2009), 56-66.

2 Official Report by the International Indian Treaty Council (IITC), "International NGO Conference on Discrimination against Indigenous Population in the Americas, 20-23 September 1977," Treaty Council News 1, 7 (1977), available at http://www.docip.org/Online-Documentation.32.0.html.

3 See Judith Goldstein, Miles Kahler, Robert O. Keohane and Anne-Marie Slaughter, "Introduction: Legalization and World Politics," International Organization 54, 3 (2000): 385-399, http://dx.doi. org/10.1162/002081800551262; and Margaret E. Keck and Kathryn Sikkink, Activists Beyond Borders: Advocacy Networks in International Politics (Ithaca: Cornell University Press, 1998), 2. The concept of a transnational advocacy network refers to how individuals and groups from different counties promote shared values and a common discourse in order to facilitate the flow of information, thereby creating new issues and categories as means of political persuasion and power.

4 IITC, "International NGO Conference on Discrimination against Indigenous Population in the Americas," 25.

5 Henceforth, the words genocide, cultural genocide, and ethnocide will be italicized when discussed in terms of rhetoric rather than as an actual phenomenon. See Perry S. Bechky, "Lemkin's Situation: Toward a Rhetorical Understanding of Genocide," Brooklyn Law Review 77, 2 (2012): 551, n. 5: "For example: Hitler committed genocide; [Raphael] Lemkin invented genocide." Similarly, see Paul Boghossian, "The Concept of Genocide," Journal of Genocide Research 12, 1-2 (2010): 80, n. 1. For genocide as a keyword, see A. Dirk Moses, “Genocide," Australian Humanities Review 55 (2013): 23-44.

6 IITC, "International NGO Conference on Discrimination against Indigenous Population in the Americas," 31.

7 Elisa Novic, "Physical-Biological or Socio-Cultural 'Destruction' in Genocide? Unravelling the Legal Underpinnings of Conflicting Interpretations," Journal of Genocide Research, 15, 1 (2015): 63-82. http://dx.doi. org/10.1080/14623528.2015.991208

8 Ibid, 7-8. See also Elisa Novic, “Physical-Biological or Socio-Cultural `Destruction' in Genocide? Unravelling the Legal Underpinnings of Conflicting Interpretations," Journal of Genocide Research 17, 1 (2015): 63-82. http://dx.doi.org/10.1080/14623528.2015.991208

9 IITC, “International NGO Conference on Discrimination against Indigenous Population in the Americas," 18. 
10 Michael A. McDonnell and A. Dirk Moses, "Raphael Lemkin as Historian of Genocide in the Americas," Journal of Genocide Research 7, 4 (2005): 501-29. http://dx.doi.org/10.1080/14623520500349951

11 Patrick Wolfe, "Structure and Event: Settler Colonialism, Time, and the Question of Genocide," in Colony, Empire, Genocide: Conquest, Occupation, and Subaltern Resistance in World History, ed. A. Dirk Moses (New York: Berghahn, 2008), 105 and 116. See also idem, "Settler Colonialism and the Elimination of the Native," Journal of Genocide Research 8, 4 (2006): 387-409. For a focus on "transfer" rather than "elimination," per se, see Lorenzo Veracini, Settler Colonialism: A Theoretical Overview (New York: Palgrave, 2010), 33-52.

12 Damien Short, "Australia: A Continuing Genocide?" Journal of Genocide Research 12, 1-2 (2010): 48-49; and A. Dirk Moses, "Empire, Colony, Genocide: Keywords and the Philosophy of History," in Colony, Empire, Genocide, 13.

13 See David Moshman, "Conceptions of Genocide and Perceptions of History," in The Historiography of Genocide, ed. Dan Stone (New York: Palgrave Macmillan, 2008), 88-89; and A. Dirk Moses, "The Field of Genocide Studies," in The Discipline of Genocide Studies, Vol. I, Genocide, ed. A. Dirk Moses (New York: Routledge, 2010), 1-23.

14 Samuel Moyn, The Last Utopia: Human Rights in History (Cambridge, MA: Belknap Press of Harvard University, 2010), 122. See also Jan Eckel and Samuel Moyn, eds., The Breakthrough: Human Rights in the 1970s (Philadelphia: University of Pennsylvania Press, 2014).

15 But see Jochen Kemner, "Fourth World Activism in the First World: The Rise and Consolidation of European Solidarity with Indigenous Peoples," Journal of Modern European History 12, no. 2 (2014): 262-279. http://dx.doi.org/10.17104/1611-8944_2014_2 262

16 Sally Engle Merry, Human Rights and Gender Violence: Translating International Law into Local Justice (Chicago: University of Chicago Press, 2006); Mark Goodale and Sally Engle Merry, eds., The Practice of Human Rights: Tracking Law between the Global and the Local (New York: Cambridge University Press, 2007), http://dx.doi.org/10.1017/CBO9780511819193; and Shannon Speed, Rights in Rebellion: Indigenous Struggle and Human Rights in Chiapas (Stanford: Stanford University Press, 2008). For anthropologists as actors in this process, see Robert Paine, ed., Advocacy and Anthropology: First Encounters (St. John's, Newfoundland: Institute of Social and Economic Research, Memorial University of Newfoundland, 1985); and Louise Lamphere, "David Maybury-Lewis and Cultural Survival: Providing a Model for Public Anthropology, Advocacy, and Collaboration," Anthropological Quarterly 82, 4 (2009): 1049-54, http://dx.doi.org/10.1353/ anq.0.0087.

17 Keck and Sikkink, Activists Beyond Borders; Alison Brysk, From Tribal Village to Global Village: Indian Rights and International Relations in Latin America (Stanford: Stanford University Press, 2000); and Neta C. Crawford, Argument and Change in World Politics: Ethics, Decolonization, and Humanitarian Intervention (New York: Cambridge University Press, 2002).

18 Moses, "Genocide," 24; Brian Grodsky, "When Two Ambiguities Collide: The Use of Genocide in SelfDetermination Drives," Journal of Genocide Research 14, 1 (2012) 1-27, http://dx.doi.org/10.1080/14623528. 2012.649893; and Brad Simpson, "The Biafran Secession and the Limits of Self-Determination," Journal of Genocide Research 16, 2-3 (2014): 337-54.

19 Ronald Niezen, The Rediscovered Self: Indigenous Identity and Cultural Justice (Ithaca: McGill-Queens Press, 2009), 6-7.

20 Idem, Truth and Indignation: Canada's Truth and Reconciliation Commission on Indian Residential Schools (Toronto: University of Toronto Press, 2013), xii.

21 Christopher Powell, "What Do Genocides Kill? A Relational Conception of Genocide," Journal of Genocide Research 9, 4 (2007): 527-47. http://dx.doi.org/10.1080/14623520701643285

$22 \mathrm{My}$ thanks to the anonymous reviewer for this point. See also Jeff Benvenuto, "Revisiting Choctaw Ethnocide and Ethnogenesis: The Creative Destruction of Colonial Genocide," in Colonial Genocide in Indigenous North America, eds. Andrew Woolford, Jeff Benvenuto, and Alexander Laban Hinton (Durham: Duke University Press, 2014), 208-227.

23 William Schabas, Genocide in International Law: The Crimes of Crimes (Second ed.) (New York: Cambridge University Press, 2000 [2009]), 207-221; David L. Nersessian, "Rethinking Cultural Genocide under International Law," Human Rights Dialogue 12, 7 (2005), available at http://www.cceia.org/resources/ publications/dialogue/2 12/section 1/5139.html; and Robert van Krieken, "Cultural Genocide in Australia," in The Historiography of Genocide, 128-155. For the broader historical context of the UNGC's creation, see Martin Shaw, Genocide and International Relations: Changing Patterns in the Transitions of the Late Modern World (New York: Cambridge University Press, 2013), 86-97.

24 This follows the approach outlined in Alexander Laban Hinton, “Critical Genocide Studies," Genocide Studies and Prevention 7, 1 (2012): 4-15. 
25 Secretary-General, Draft Convention on the Crime of Genocide, UN Doc. E/447 (26 June 1947), reproduced in Hirad Abtahi and Philippa Webb, eds., The Genocide Convention: The Travaux Préparatoires (Vol. 1) (Boston: Martinus Nijhoff), 231.

26 Ibid, 235.

27 Raphael Lemkin, "The Concept of Genocide in Anthropology," in Lemkin on Genocide, ed. Steven Leonard Jacobs (New York: Lexington, 2012), 41.

28 A. Dirk Moses, "Raphael Lemkin, Culture, and the Concept of Genocide," in The Oxford Handbook of Genocide Studies, eds. Donald Bloxham and A. Dirk Moses, (New York: Oxford University Press, 2010), 22-3; and Douglas Irvin-Erickson, "Genocide, the 'Family of Mind' and the Romantic Signature of Raphael Lemkin," Journal of Genocide Research 15, 3 (2013): 273-296, http://dx.doi.org/10.1080/14623528.2013.821222.

29 Mark Mazower, No Enchanted Palace: The End of Empire and the Ideological Origins of the United Nations (Princeton: Princeton University Press, 2009), 104-148.

30 United States delegate, $3^{\text {rd }}$ Session of the General Assembly, 6th Committee, 83rd meeting, UN Doc. A/C.6/ SR.83 (25 October 1948), reproduced in The Genocide Convention (Vol. 2), 1514.

31 Brazilian delegate, in ibid, 1507.

32 Venezuelan delegate, in ibid, 1504.

33 Audrey Jane Roy, "Sovereignty and Decolonization: Realizing Indigenous Self-Determination at the United Nations and in Canada," (MA Thesis: University of Victoria, Department of Indigenous Governance, 2001), 4-23.

34 Clifford Geertz, "The Integrative Revolution: Primordial Sentiments and Civil Politics in the New States," in The Interpretation of Cultures: Selected Essays (New York: Basic, 1973), 255-310.

35 Luis Rodríguez-Piñero, Indigenous Peoples, Postcolonialism, and International Law: The ILO Regime (1919-1989) (New York: Oxford University Press, 2005), 173-211.

36 Covenant of the League of Nations, Article 22.

37 Laura Giraudo and Stephen E. Lewis, "Pan-American Indigenismo (1940-1970): New Approaches to an Ongoing Debate," Latin American Perspectives 39, 5 (2012): 3. See also Rodríguez-Piñero, Indigenous Peoples, Postcolonialism, and International Law, 53-82.

38 International Labour Organization Convention No. 107, Article 1(1); and Article 2(1).

39 Ibid, Article 7(1).

40 For a list of ratifications, see http://www.ilo.org/dyn/normlex/en/f?p=1000:11300:0::NO:11300:P11300 INSTRUMENT ID:312252.

41 Ronald Niezen, The Origins of Indigenism: Human Rights and the Politics of Identity (Berkeley: University of California Press, 2003), 36-40, http://dx.doi.org/10.1525/california/9780520235540.001.0001; and RodríguezPiñero, Indigenous Peoples, Postcolonialism, and International Law, 257-290.

42 Commission on Human Rights, "Report of the Sub-Commission on Prevention of Discrimination and Protection of Minorities on the Work of its Twenty-fourth Session," UN Doc E/CN.4/Sub.2/323 (6 October 1971), 59-60. In 1999, the Sub-Commission on the Prevention of Discrimination and Protection of Minorities was renamed the Sub-Commission on the Promotion and Protection of Human Rights.

43 Sub-Commission on Prevention of Discrimination and Protection of Minorities, "Study of the Question of the Prevention and Punishment of the Crime of Genocide: Study Prepared by Mr. Nicodème Ruhashyanlciko, Special Rapporteur," (hereafter cited as the Ruhashyankiko report) UN Doc. E/CN.4/ Sub.2/416 (4 July 1978), 1 and 127-128.

44 The report cites Robert Jaulin, ed., L'ethnocide à travers les Amériques, Textes et documents (Anthropologie critique, Collection dirigée par Alain Gheerbrant) (Paris, Librairie Arthème Fayard, 1972). See also idem, La Paix blanche: Introduction à l'ethnocide (Paris: Éditions du Seuil, 1970); and Julian Pitt-Rivers and Robert Jaulin, "Ethnology and History," RAIN 3 (1974): 1-3.

45 Schabas, Genocide in International Law, 555-559; and Sub-Commission on Prevention of Discrimination and Protection of Minorities, "Review of Further Developments in Fields with which the Sub-Commission has been Concerned: Revised and Updated Report on the Question of the Prevention and Punishment of the Crime of Genocide Prepared by Mr. B. Whitaker," (hereafter cited as the Whitaker report) UN Doc. E/ CN.4/Sub .2/1985/6 (2 July 1985).

46 Ibid, 9-10, citing Richard Arens, ed., Genocide in Paraguay (Philadelphia: Temple University Press, 1976). The Aché are indigenous to the heavily forested region of eastern Paraguay, where they avoided colonial contact for centuries, before the military dictatorship of Paraguay slated the area for development in the 1950s. According to contemporaneous accounts, the Aché were especially subjected to forcible removals and massacres. 
47 Mark Münzel, The Aché Indians: Genocide in Paraguay (Copenhagen: IWGIA Document No. 11, 1973). Cf. David Maybury-Lewis and James Howe, The Indian Peoples of Paraguay: Their Plight and Their Prospects (Cambridge, MA: Cultural Survival Special Report no. 2, 1980). For background on the NGO debate, see Alejandro Parellada and María de Lourdes Beldi de Alcántara, eds., Los Aché del Paraguay: Discusión de un Genocidio (Copenhagen: International Work Group on Indigenous Affairs, 2008); and Richard Reed and John Renshaw, "The Aché and Guaraní: Thirty Years after Maybury-Lewis and Howe's Report on Genocide in Paraguay," Tipití: Journal of the Society for the Anthropology of Lowland South America 10, 1 (2012): 1-18.

48 Elie Wiesel, “Now We Know," (translated by Raymond Federman), in Genocide in Paraguay, 165-166.

49 Sub-Commission on Prevention of Discrimination and Protection of Minorities, "Study of the Problem of Discrimination against Indigenous Populations: Final Report (Supplemental Part) Submitted by the Special Rapporteur, Mr. Jose R. Martinez Cobo," UN Doc. E/CN.4/Sub.2/1982/2/Add.6 (20 June 1982). See also S. James Anaya, Indigenous Peoples in International Law (Second ed.) (New York: Oxford University Press, 2004 [1996]), 62-63.

50 Sub-Commission on Prevention of Discrimination and Protection of Minorities, "Study of the Problem of Discrimination against Indigenous Populations: Final Report (Last Part) Submitted by the Special Rapporteur, Mr. Jose R. Martinez Cobo," UN Doc E/CN.4/Sub.2/1983/21/Add.3 (17 June 1983), 16.

51 The Whitaker report, 17.

52 Declaration of San José, adopted by the UNESCO Meeting of Experts on Ethno-Development and Ethnocide in Latin America, San José, December 11, 1981, UNESCO Doc. FS 82/WF.32 (1982). It is reproduced in Anaya, Indigenous Peoples in International Law, 301.

53 Ibid. On this keyword more generally, see Karen Engle, The Elusive Promise of Indigenous Development: Rights, Culture, Strategy (Durham: Duke University Press, 2010), 190-6.

54 ILO Convention No. 169, preamble paragraph 5.

55 Idem, Article 1(3). See also Rodríguez-Piñero, Indigenous Peoples, Postcolonialism, and International Law, 3078; and Anaya, Indigenous Peoples in International Law, 59-60.

56 United Nations Declaration on the Rights of Indigenous Peoples, Article 46, Section 1.

57 Rodríguez-Piñero, Indigenous Peoples, Postcolonialism, and International Law, 281-3.

58 Economic and Social Council Resolution 1982/34, "Study of the Problem of Discrimination against Indigenous Populations," UN Doc. E/RES/1982/34 (7 May 1982).

59 Augusto Willemsen-Diaz, "How Indigenous Peoples' Rights Reached the UN," in Making the Declaration Work: The United Nations Declaration on the Rights of Indigenous Peoples, eds. Claire Charters and Rodolfo Stavenhagen (Copenhagen: IWGIA, 2009), 28. See also Erica-Irene Daes, "The UN Declaration on the Rights of Indigenous Peoples: Background and Appraisal," in Reflections on the UN Declaration on the Rights of Indigenous Peoples, eds., Stephen Allen and Alexandra Xanthaki (Oxford: Hart Publishing, 2011), 11-40.

60 Douglas Sanders, “The UN Working Group on Indigenous Populations," Human Rights Quarterly 11, 3 (1989): 408. For evidence, see Sub-Commission on Prevention of Discrimination and Protection of Minorities, "Report of the Working Group on Indigenous Populations to the Sub-Commission on Prevention of Discrimination and Protection of Minorities on the Work of its First Session," UN Doc. E/ CN.4/Sub.2/1982/33 (25 August 1982), para. 77; and Sub-Commission on Prevention of Discrimination and Protection of Minorities, "Report of the Working Group on Indigenous Populations to the Sub-Commission on Prevention of Discrimination and Protection of Minorities on the Work of its Third Session," UN Doc. E/CN.4/Sub.2/1984/20 (8 August 1984), para. 55. http://dx.doi.org/10.2307/762100

61 Commission on Human Rights, "Report of the Working Group on Indigenous Populations to the SubCommission on Prevention of Discrimination and Protection of Minorities on the work of its fifth session," UN Doc. E/CN.4/Sub.2/1987/22 and Add.1 (24 August 1987), para. 31.

62 The 1994 draft declaration is sometimes confusingly dated to 1993, because although the draft itself was completed at the eleventh session of the Working Group in August 1993, it was not formally adopted until the 1994 meeting of the Sub-Commission. For the complete text of the 1994 Draft Declaration, see SubCommission on Prevention of Discrimination and Protection of Minorities Resolution 1994/45 (hereafter cited as the 1994 Draft Declaration), in Commission on Human Rights, "Report of the Sub-Commission on Prevention of Discrimination and Protection of Minorities on the Work of its Forty-sixth Session," UN Doc. E/CN.4/Sub.2/1994/56 (28 October 1994), 105-15.

63 Irene Watson and Sharon Venne, “Talking up Indigenous Peoples' Original Intent in a Space Dominated by State Interventions," in Indigenous Rights in the Age of the UN Declaration, ed. Elvira Pulitano (New York: Cambridge University Press, 2012), 89, http://dx.doi.org/10.1017/cbo9781139136723.004; and Charmaine White Face (Zumila Wobaga), Indigenous Nations' Rights in the Balance: An Analysis of the Declaration on the Rights of Indigenous Peoples (St. Paul, MN: Living Justice, 2013), xi. 
64 Kenneth Deer, "Reflections on the development, Adoption, and Implementation of the UN Declaration on the Rights of Indigenous Peoples," in Realizing the UN Declaration on the Rights of Indigenous Peoples: Triumph, Hope, and Action, eds. Jackie Hartley, Paul Joffe, and Jennifer Preston (Saskatoon: Purich, 2010), 20-1; and White Face, Indigenous Nations' Rights in the Balance, 1-2.

651994 Draft Declaration, Article 6.

66 Ibid, Article 7.

67 Sub-Commission on Prevention of Discrimination and Protection of Minorities, "Technical Review of the United Nations Draft Declaration on the Rights of Indigenous Peoples: Note by the Secretariat," UN Doc. E/CN.4/Sub.2/1994/2 (5 April 1994), para. 15.

68 Commission on Human Rights, "Report of the Working Group Established in Accordance with Commission on Human Rights resolution 1995/32 of 3 March 1995 on the Work of its First Session," UN Doc. E/CN.4/1996/84 (4 January 1996), para. 64; and Commission on Human Rights, "Report of the Working Group Established in Accordance with Commission on Human Rights resolution 1995/32 of 3 March 1995 on the Work of its Second Session," UN Doc. E/CN.4/1997/102 (10 December 1996), paras. 183, 186 , and 188.

69 Commission on Human Rights, "Report of the Working Group established in accordance with Commission on Human Rights resolution 1995/32 of 3 March 1995 on the work of its first session," UN Doc. E/ CN.4/1996/84 (4 January 1996), para. 61.

702006 Draft Declaration, Article 7, Section 2. The 2006 Draft Declaration was published in "Report of the Human Rights Council: First Session (19-30 June 2006), First Special Session (5-6 July 2006),Second Special Session (11 August 2006)," UN Doc. A/61/53 (2006).

71 Cf. 1994 Draft Declaration, Article 6; and 2006 Draft Declaration, Article 7(2).

722006 Draft Declaration, Article 8(1).

73 UN Department of Public Information, News and Media Division, “Third Committee Approves Draft Resolution on Right to Development; Votes to Defer Action Concerning Declaration on Indigenous Peoples," (November 28, 2006), available at http://www.un.org/News/Press/docs/2006/gashc3878.doc.htm. See also Siegfried Wiessner, "Indigenous Sovereignty: A Reassessment in Light of the UN Declaration on the Rights of Indigenous Peoples," Vanderbilt Journal of Transitional Law 41, 4 (2008): 1159-1166.

74 Cf. 2006 Draft Declaration, Article 8(2)(d); and United Nations Declaration on the Rights of Indigenous Peoples, Article 8(2)(d). See also White Face (Zumila Wobaga), Indigenous Nations' Rights in the Balance, 49.

75 Lillian Aponte Miranda, “Indigenous People as International Lawmakers," University of Pennsylvania Journal of International Law 32, 1 (2010): 261-2; and Sheryl R. Lightfoot, "Selective Endorsement without Intent to Implement: Indigenous Rights and the Anglosphere," International Journal of Human Rights 16, 1 (2012): 100-122, http://dx.doi.org/10.1080/13642987.2012.622139.

76 Antony Anghie, Imperialism, Sovereignty and the Making of International Law (New York: Cambridge University Press, 2004), 273-309; and Samuel Moyn, Human Rights and the Uses of History (Brooklyn, NY: Verso, 2014), 35-52.

77 Irene Watson, "Aboriginal(ising) International Law and Other Centres of Power," Griffith Law Review 20, 3 (2011): 629, http://dx.doi.org/10.1080/10383441.2011.10854713. See also Colin Samson and Damien Short, "The Sociology of Indigenous Peoples' Rights," in Rights: Sociological Perspectives, ed. Lydia Morris (New York: Routledge, 2006), 178-80; and H. Patrick Glenn, "The Three Ironies of the UN Declaration on the Rights of Indigenous Peoples," in Reflections on the UN Declaration on the Rights of Indigenous Peoples, 176.

78 Dale Turner, This Is Not a Peace Pipe: Towards a Critical Indigenous Philosophy (Buffalo: University of Toronto Press, 2006), 12-37; Taiaiake Alfred, Peace, Power, Righteousness: An Indigenous Manifesto (Second ed.) (New York: Oxford University Press, 2009 [1999]); and Peter Kulchyski, “Aboriginal Rights are not Human Rights," Prairie Forum 36 (2011): 33-53.

79 Anaya, Indigenous Peoples in International Law, 131-41; and idem, "Indian Givers: What Indigenous Peoples Have Contributed to International Human Rights Law," Washington University Journal of Law \& Policy 22 (2006): 116. See also Jeff J. Corntassel and Tomas Hopkins Primeau, "Indigenous 'Sovereignty' and International Law: Revised Strategies for Pursuing 'Self-Determination'," Human Rights Quarterly 17, 2 (1995):365; and Lorie M. Graham and Sigfried Wiessner, "Indigenous Sovereignty, Culture, and International Human Rights Law," South Atlantic Quarterly 110, 2 (2011): 413-9, http://dx.doi.org/10.1215/003828761162516. Cf. Engle, The Elusive Promise of Indigenous Development, who instead argues that such emphasis on cultural rights has displaced more assertive claims for self-determination. It is not clear, however, that this necessarily implies a zero-sum payoff. See Kristy Gover, "Review Essay," Melbourne Journal of International Law 12, 2 (2011): 419-31.

80 Grodsky, “When Two Ambiguities Collide," 2. 
81 It is worth briefly noting how the Indigenous right to cultural integrity interlinks with other Indigenous rights, including treaty rights. While treaty rights are central to many Indigenous rights discourses in North America, in other parts of the world where the history of treaty relations is non-existent, these types of rights do not offer much promise. In comparison, the right to cultural integrity is more universally shared across the situations of Indigenous peoples worldwide. See Corntassel and Primeau, "Indigenous 'Sovereignty' and International Law,' 358-60.

82 IITC, “International NGO Conference,” 18.

83 "Hard" and "soft" law is distinguished by the degree to which a protocol is legally binding. See Kenneth W. Abbott and Duncan Snidal, "Hard and Soft Law in International Governance," International Organization 53, 3 (2000): 421-56; and Mauro Barelli, "The Role of Soft Law in the International Legal System: The Case of the United Nations Declaration on the Rights of Indigenous Peoples," International and Comparative Law Quarterly 58, 4 (2009): 957-83, http://dx.doi.org/10.1017/S0020589309001559.

84 Andrew Woolford, “Ontological Destruction: Genocide and Canadian Aboriginal Peoples," Genocide Studies and Prevention 4, 1 (2009): 81-97, http://dx.doi.org/10.1353/gsp.0.0010; Jeff Benvenuto, Andrew Woolford, and Alexander Laban Hinton, "Introduction: Colonial Genocide and Indigenous North America," in Colonial Genocides in Indigenous North America, 12-13; Andrew Woolford, "Discipline, Territory, and the Colonial Mesh: Indigenous Boarding Schools in the United States and Canada," in Colonial Genocides in Indigenous North America, 44; and Tricia E. Logan, "Memory, Erasure, and National Myth," in Colonial Genocides in Indigenous North America, 149-65. 